- Service Management

- Virtual Networks and Decentralized Management Algorithms

- Multi-Layer Network Configuration and Management

- Autonomic Management

- Problem Detection and Topology Management

- IT Management

- Service Information Management

- Management of Ad-hoc and Personal Networks

- Routing Management

- Performance of Grid

またアプリケーションセッションは下記の 3 テーマで行われ た.

- Business and Service Management

- Grid, Security and Protocols

- Wireless and Autonomic Management

各セッションの動向については，以下の専門家の方々による 報告記事を参照頂きたい.

次回は，2009 年に日本で開催される予定である.

\section{発表に見る運用管理技術の 動问}

(株) KDDI 研究所 鶴沢宗文

会議は実質 3 日間（火〜木）で行われたが，会議における セッションに加えて月曜日のチュートリアルや最終日のワー クショップにおいても「Autonomic（自律的）」を冠した発表 が多数あり, オートノミックコンピューティング並びにオー トノミックネットワーキングという技術的学問分野の確固た る存在を再認識した。「オートノミック技術」が目指すところ は各種の運用におけるディシジョンポリシーの動的変更によ り最適化が行われるフィードバックシステムである。運用者 やユーザの設定したポリシーに従って自動変更や回復が行わ れるシステムは「オートマチック」と定義され，ポリシーその ものが系のフィードバックにより変更されることをオートノ ミックと分類している．前出のようにセッションテーマが多 岐にわたり，かつ 1 セッションの発表件数も最大 4 件と限ら れるため系統的に動向を述べることは難しいが，下記に注目 した発表を列記する。

University of Ottawa (Canada)より報告された論文 [1] で は，大規模 IP ネットワーク上に様々なオーバレイネット ワークが構成される場合には Autonomic（自律的）な設定・ マネージメント手法を適用した方がスケーラブルかつネット ワーク側の負荷分散などの点で有利であるという提案が示さ れた。実験 (シミュレーション) では Self-Organizing, Graph Based Approach, Limited-Flooding, SO with LF (SO+:
Autonomic）の手法についてサービス数とネットワーク負荷 などを比較して，SO+の手法が有利であることを証明した。

University of Rio Grande do Sul (Brazil)からは IT リソー スの設定変更手法に関する報告 [2]が行われた。通常，IT インフラの設定・構成変更では各リソースの設定ファイルの 変更を行い, 内容をリロードして実行しないと最終的なシス テム全体へのインパクトが分からない.この提案ではシステ ムの設定変更に対して変更プロセスを体系化して各フェイズ における設定変更の履歴を保持することにより，オペレータ のナレッジを設定変更前後の計画策定とインパクト予測に有 効に反映すると同時に履歴のデータマイニングによる設定変 更計画の策定サポートなどを可能にすることを目的としてい る、設定の世代管理のみならずプロセスそのものを標準化す るという構想が参考になった。

運用管理手法については制御プレーン，管理プレーンにお ける工夫についての発表が多い中, KDDI 研究所からはレイ ヤ2 ネットワークのデータプレーンの運用管理技術に関する 報告された [3]. ITU-T Y.1731をベースとしたイーサネッ ト OAM 技術について実ネットワーク機器と PC ベースのエ ミュレータを用いた実験的検証を行い，ネットワーク遅延や フレームロスなどのパフォーマンス劣化をレイヤ 2 レベルで 発生箇所の特定が可能であることを実証した.

高速・低廉化するインタフェースにおける高速トラヒック モニタリング技術について ETRI (Electronics and Telecommunications Research Institute, Korea）から報告が行わ れた [4]. フローベースのトラヒックモニタリング技術はソ フトウェアによる解析技術の進展に伴って進化しているが, $1 \mathrm{Gbit} / \mathrm{s}$ 以上のレートで取り扱うためにはハードウェアベー スのサポートが求められている。また高速化対応のために ヘッダ部だけをキャプチャする方式もあるがファイアウォー ル回避のために一般的なポート番号を使うアプリケーション もありフローの判別には不十分なケースも出てきている.こ の報告ではネットワークプロセッサベースのモニタリング機 構と複数のハッシュテーブルからなる Multi-Stage Filtering Algorithm と称するサンプリング手法を実装し， $1 \mathrm{Gbit} / \mathrm{s}$ に おけるパケットロスなしのフローモニタリングを実証した.

最終日に開催されたワークショップ “2nd IEEE Workshop on Autonomic Communication and Network Management (ACNM 2008)”において, アイルランドの Waterford Institute of Technology/Telecommunications Software \& Systems Group (TSSG) による招待講演が行われた. TSSG には Autonomic Networking の分野で著名な Motorola Lab の上級研究員もジョイントしており, TSSGが取り組む Autonomic Networking の研究は非常に高い次元で行われて いる. 講演 [5]では Knowledge Analysisによるポリシーメ イキング, Policy Processingによるネットワーク設定，ネッ トワークの状態把握に基づく Knowledge Base の再構築と更 なる Knowledge Analysisへのフィードバックシステムがセ グメントごとに詳述され，実験結果と併せて有用性が説明さ 
れた，講演の中では，一見，完全自動運用に思われるオート ノミック運用であるが, 実は運用者の経験・知見に基づくディ シジョンポリシーの初期設定や所望のビジネスゴールをよく 分析した上での運用ポリシーの決定など，システム設計にお ける人智の優劣が大きな影響を及ぼすことなどが説明され た。

\section{総 括}

以上, いくつかのセッションにおける発表論文の概要を述 ベたＩCTリソースの進展に伴い運用管理機構は高度化し ており，運用管理技術の研究課題は自律的運用の実現とその ためのナレッジシステムの高度化に向かっているということ が本会議の採択論文からうかがえた。またネットワーク運用 技術についてもデータプレーンのモニタリングやルーチング 手法の高度化だけでなく運用管理機構 (サーバ) との連携技術 に関する発表が目立った。これら次世代運用管理技術の具現 化による通信サービスの高度化と低廉化の両立は広く社会に 資すると考えられ，今後の運用管理技術の進展に期待したい。

\section{文献}

[1] I. Aloqily and A. Karmouch, "A self-organizing composition towards autonomic overlay networks," TS10-1.

[2] W. Cordeiro, C. Both, L. P. Gaspary, and L. Z. Granville, "A template-based solution to support knowledge reuse in IT change design," TS12-1.

[3] M. Tsurusawa and Y. Horiuchi, "Feasibility validation of management capability for an Ethernet based access network using Ethernet OAM functionality," AS2-4.

[4] T. Choi, S. Yoon, D. Kang, S. Kim, and J. Lee, "Wirespeed application flow generation in hardware platform for multi-gigabit traffic monitoring," TS6-4.

[5] B. Jennings, "Autonomic network management: how do we govern self-managing networks?," 2nd Workshop on IEEE Autonomic Communications and Network Management, Invited paper.

\section{無線関連セッションの動向 日本電気株式会社 渡邊吉則}

\section{概 要}

NOMS 2008 では，無線通信網の運用管理に関して三つの セッションが設けられ，計 11 件の発表が行われた。いずれ のセッションも $30 \sim 50$ 名程度の聴講者が参加し, 活発な質 疑応答が交わされるなど, 関心の高さがうかがえた。発表の 内訳は, 大学からの発表が 6 件, 企業からの発表が 5 件と, 産学からバランス良く論文が選ばれており, 大学は私設網に 関する発表，企業は公衆網に関する発表が中心であった。ま た，通信網の運用管理に関する発表のほか, 経路選択や無線
資源選択の最適化など通信方式に関する論文も取り上げられ ていたが，本稿では主に前者の研究動向について報告する.

\section{主要トピックス}

第三世代移動通信網 (以下， $3 \mathrm{G}$ 網）のように普及期を迎え た無線網では，多数のユーザの通信品質を維持し，既設網の 運用管理を効率化して OPEX (Operational Expenditure) を 削減することが経営上の重要課題となる。文献 [1]では，公 衆移動網の運用管理で一般に多くの工数を要する網の異常検 出・原因分析の作業を効率化するシステムを提案していた。 同発表では，無線セルのトラヒック量を考慮して算出した統 計的信頼度を用いる異常検出と，無線網の運用ログに独立成 分分析を適用した原因分析により，網異常の誤検出を削減で きることを商用 $3 \mathrm{G}$ 網において確認していた.

一方, WiMAX など今後敷設が進むと考えられる次世代の 高速無線通信網は, CAPEX (Capital Expenditure) の削減 が至上命題である。特に，高速デー夕通信を提供する無線網 では，一部のユーザが無線資源を大量に消費するとエリア品 質が劣化してしまうという課題がある，文献 [2]では，商用 WiMAX 網において CPE (Customer Premises Equipment) 単位にトラヒック監視を行い，網に過剩な負荷を掛ける CPEに対して段階的な利用制限を加えることで，適切な資 源管理を図っていた。

更に, OPEXの削減に向けた網の構成管理の自律化につ いて，無線セル間のハンドオーバのためにあらかじめ設定し ておく隣接セルリストの自動的な最適化に関する 2 件の発表 があった [3]， [4]. 文献 [3] では，動的なべイズネットワー クとポリシールールを用いた状況判断により，障害が発生し た無線セルを隣接セルリストから自律的に除外できることを シミュレーションにより確認していた。また, 文献 [4] では, LTE（3G Long Term Evolution）における同様な隣接セルリ ストの更新を，端末がハンドオーバの際に行う測定結果を用 いて網側で自律的に行う方式を提案していた。

以上の発表は, 単独の通信事業者において運用管理業務及 び設備投資の効率化を図るアプローチであった。一方, 近年, 複数の通信事業者の間で通信インフラを共有することによる 設備投資の効率化が注目されており，文献 [5]では，通信 インフラの様々な共有形態に応じた OPEX と CAPEX の削 減効果の試算結果を報告していた。同発表では，無線基地局 のサイト共有や，無線アクセス網に掞ける通信装置の共有な ど多様な観点から通信インフラの共有シナリオが整理され, 各国の法規制なども考慮しながら各々の得失の比較がなされ ていた.

そのほかでは, Ad-hoc Networkや Mesh Networkなど Multi-Hop タイプの新しい無線通信網を想定した管理系が提 案され注目を集めていた [6].

\section{総括}

以上に述べたとおり，無線網の運用管理においては OPEX と CAPEX の削減が重要課題であり，本会議におい ても関連する発表が見られた。NOMSの発表全般にいえる 
ことだが，同会議では運用管理の対象とする装置系の振舞い を数理モデルで表現し, 解析的手法により課題を解決するア プローチが多い，一方で，筆者は装置系のみならず系の利用 者のヒューマンファクタも含めて解析的に取り扱った運用管 理の研究を積極的に推進することも必要と考える。例えば, 通信サービスに対して寄せられるユーザクレームを効果的に 対処する管理手法など，ユーザの個別性を配慮して通信サー ビスに対するユーザの満足度を向上させる管理系の提案など が今後現れることを期待したい.

文献

[1] Y. Watanabe, Y. Matsunaga, K. Kobayashi, T. Tonouchi, T. Igakura, S. Nakadai, and K. Kamachi, "UTRAN O\&M support system with statistical fault identification and customizable rule sets," AS3-1.

[2] Q. Zhang and H. Dam, "WiMAX network performance monitoring \& optimization," AS3-2.

[3] J. Baliosian, K. Matusikova, K. Quinn, and R. Stadler, "Policy-based self-healing for radio access networks," PS4-20.

[4] M. Amirijoo, P. Frenger, F. Gunnarsson, H. Kallin, and J. Moe, "Neighbor cell relation list and measured cell identity management in LTE," TS5-4.

[5] T. Frisanco, P. Tafertshofer, P. Lurin, and R. Ang, "Infrastructure sharing and shared operations for mobile network operators from a deployment and operations view," TS5-1.

[6] B. Mathieu, F. Jan, and D. Meddour, "A monitoring tool for wireless multi-hop mesh networks,” AS3-3.
なるノードから構成されるクラスタでは, 同じ異常でもそれ による測定值の変化は一定ではない。ここでは，測定值につ いて固有空間法を用い, 変化の特徴值を抽出し, 更にクラス タリングによって異常ノードを特定する。これによって必要 となる観測值の数を減らし，より大規模なクラスタへの適用 も可能となっている.

[3] では, BGP updateメッセージの頻度が自己相似性 （self-similarity）を有することを利用し，ウェーブレット変 換を適用することで通常とは異なる数の BGP update メッ セージの発生を検知し, ネットワーク上の経路異常を検出し ている。実データによる検証でも，過去の経路異常を正しく 検出できていることが示されている.

文献

[1] E. Freire, A. Ziviani, and R. Salles, "Detecting skype flows in Web traffic," TS3-4.

[2] M. Agarwal, "Eigan space method for detecting faulty nodes in large scale," TS8-1.

[3] J. Mai, L. Yuan, and C. Chuah, "Detecting BGP anomalies with wavelet," T15-4.

(平成 20 年 6 月 29 日受付)

\section{問題検知技術関連セッシ の動向}

NOMS では, その名 (Network Operation and Management）が示すと拈り，ネットワークの管理運用の技術者・ 研究者が数多く参加する会議でもある.このため, とりわ け他の会議と比べ，様々な問題の検出・検知技術に対する 関心が高いともいえる。タイトルに Identification や Detection が含まれる論文数は全体の $10 \%$ を超え，“Identification and Classification of Internet Traffic: A Cat-and-Mouse Chase?”といったパネル討論も行われた。ここでは, それ らの論文の中から一部を紹介する.

[1] では，HTTP/HTTPS を使用することでポートベー スでは Web トラヒックと区別がつかない Skypeトラヒッ クを，統計的な性質の違いから分別する手法が提案されて いる. Web ブラウジングのデータを学習データとして用い ることで $90 \%$ 以上の検出率を達成している.

[2] では，大規模クラスタに扔いて効率良く異常ノードを 検出するための技術について提案している．特に性能の異

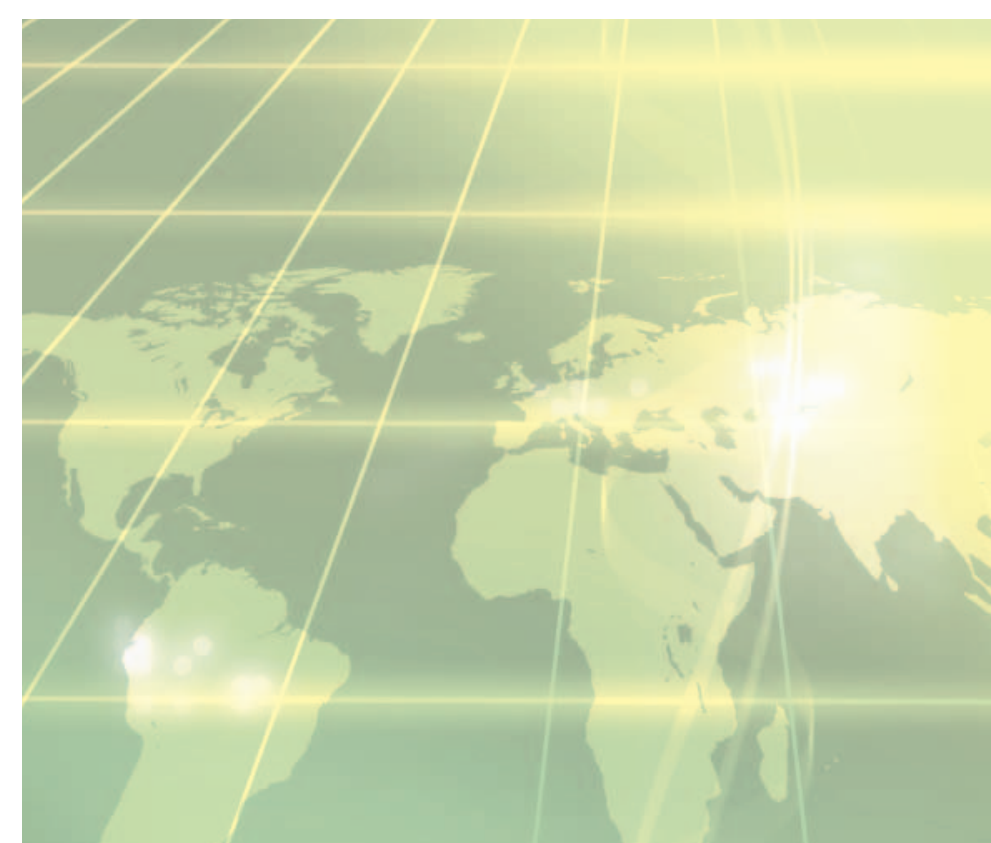

